Original Article

\title{
Syagrus flexuosa (Mart.) Becc. (Arecaceae) seedling recruitment at the edge and interior of Cerrado remnants
}

\author{
Recrutamento de plântulas em Syagrus flexuosa (Mart.) Becc. (Arecaceae), na borda e \\ interior de remanescentes de Cerrado
}

J. Ragusa-Netto ${ }^{\text {* }}$ (1)
aUniversidade Federal de Mato Grosso do Sul - UFMS, Departamento de Ciências Naturais, Três Lagoas, MS, Brasil

\begin{abstract}
The edge effect has impacts on seed and seedling survival due to modifications in biotic and abiotic factors. Often, large-seeded tree species lost seed vectors in the forest edge due to the rarity or absence of large frugivores at this habitat type. In this study, I compared the seedling abundance and distribution of the palm Syagrus flexuosa between edges and interiors of three large Cerrado remnants. In every remnant, the number of seedlings around parent palms in the edge was smaller than around palm individuals located in the Cerrado interior. Moreover, the distribution of seedlings around parent palms differed between edges and interiors. In the edges, most seedlings were found under parent crowns, while in the interiors, the contrary occurred. The high concentration of seedlings under parent palms suggests a decrease of seed dispersal at the edges. Because $S$. flexuosa is a widely distributed palm that serves as an important resource for several animals along Cerrado habitats, changes on the regeneration process of this palm due to edge effects can further impact frugivore populations. Therefore, the decline of seedling establishment along forest edges implies changes in the Cerrado regeneration dynamics, which may compromise the persistence of ecological processes and animal communities.
\end{abstract}

Keywords: edge effect, palm distribution, Cerrado palm, plant-animal interaction, vegetation fragment.

\begin{abstract}
Resumo
O efeito de borda tem impactos severos na sobrevivência de sementes e plântulas devido a modificações dos fatores bióticos e abióticos. Frequentemente, espécies arbóreas com sementes grandes perdem seus dispersores na borda da floresta devido à raridade ou ausência de grandes frugívoros neste tipo de habitat. Neste estudo, comparei a abundância e distribuição de plântulas de $S$. flexuosa entre bordas e interiores de três grandes remanescentes de Cerrado. Em cada remanescente, o número de plântulas ao redor das palmeiras-mãe, na borda, era menor do que ao redor dos indivíduos no interior do Cerrado. Nas bordas, a maioria das plântulas foi encontrada junto às plantas mãe, enquanto no interior ocorreu o contrário. A alta concentração de plântulas sob as plantas adultas sugere diminuição da dispersão de sementes nas bordas. Como S. flexuosa é uma palmeira amplamente distribuída que serve como um recurso importante para vários animais nos habitats do Cerrado, mudanças no processo de regeneração dessa palmeira devido aos efeitos de borda podem impactar ainda mais as populações de frugívoros. Portanto, o declínio do estabelecimento de plântulas ao longo das bordas do Cerrado implica em mudanças na dinâmica de regeneração do Cerrado, o que pode comprometer a persistência de processos ecológicos e comunidades animais.

Palavras-chave: efeito de borda, distribuição de palmeiras, palmeira do Cerrado, interação animal-planta, fragmento de vegetação.
\end{abstract}

\section{Introduction}

Tropical forests fragmentation often reduces the tree regeneration process as a result of ruptures in biological interactions such as seed dispersal, with subsequent effects on seedling recruitment (Benítez-Malvido, 1998; Cordeiro and Howe, 2003; Tabarelli et al., 2008; BenítezMalvido et al., 2018). This impact is particularly severe in forest fragments lacking large-bodied seed vectors due to the decline in dispersal and recruitment of large-seeded trees species, mainly at the edges (Benítez-Malvido et al.,

2018). These changes are, at least, partly driven by edge effects, the diverse physical and biotic changes associated with the abrupt artificial boundaries of habitat fragments (Laurance et al., 2006; Melo et al., 2007). Changing plant-frugivore interactions will probably change forest community characteristics, which may exacerbate the long-term species diversity loss in fragmented and disturbed tropical forests (Wright and Duber, 2001; Benítez-Malvido et al., 2018). 
Palms are one of the most abundant and diverse groups of animal-dispersed plants in the Americas (Henderson, 2002). Indeed, most palm species produce large fruits, widely consumed by large frugivores (Zona and Henderson, 1989; Muñoz et al., 2019). In this respect, studies have shown mammals as important seed vectors of Neotropical palms (Muñoz et al., 2019; Dracxler and Kissling, 2021). Although some mammals may function as both seed predators and dispersers, associations with mammalian frugivores benefit palms in terms of invertebrate seed predation avoidance, seed germination, and seedling survival due to seed dispersal by these vectors (Zona and Henderson, 1989; Dracxler and Kissling, 2021). Medium and large mammals are usually scarce in the forest edges, implying in reduced seed dispersal at this modified habitat (Asquith and Mejía-Chang, 2005; Wright et al., 2007). Consequently, edges of forest fragments typically experience significant changes in their palm community composition (Baez and Balslev, 2007; Wright et al., 2007). However, few studies focused on the responses of palm species to habitat loss and fragmentation at the population level (Souza and Martins, 2003; Mariano and Christianini, 2016). Worth note, Galetti et al. (2006) pointed out the deleterious consequences of the loss of seed-dispersing agents for the long-term sustainability of palm populations in forest remnants.

Studies in fragmented landscapes suggest that the edge effect affects palms differently (Scariot, 1999; Baez and Balslev, 2007; Browne and Karubian, 2016). Some palm species may experience an increase in their abundance in modified habitats, as forest edges (Souza and Martins, 2003; Pimentel and Tabarelli, 2004), while others decline (Arroyo-Rodríguez et al. 2007; Baez and Balslev, 2007). Basically, some palm species benefit from increased light availability (Souza and Martins, 2003) and changes in dispersal-predation dynamics, which favor palm species in terms of recruitment rates, becoming dominant after forest fragmentation (Wright et al., 2000; Pimentel and Tabarelli, 2004). On the other hand, in Amazonia, for example, the density of two species of palms and the overall species richness of the palm community tended to decrease toward the edges within forest fragments (Baez and Balslev, 2007). In view of those different patterns, desert attention the importance of understanding palm recruitment in fragmented vegetation in terms of population dynamic changes. Importantly, the Brazilian Cerrado has been severely fragmented (Carvalho et al., 2009; Beuchle et al. 2015), but no study compared palm recruitment simultaneously in the edge and the interior of remnants. In this respect, I predict the distance from the edge affects positively both seedling abundance and far distribution from parent palms due to their dependence on medium-large animal seed-vectors, which are scarce or absent along forest edges (Wright et al., 2007). Thus, in this study, I compared both Syagrus flexuosa (Mart.) Becc. seedling abundance and distribution (according to the distance from adult palms) at the edges with the interiors of Cerrado remnants.

\section{Materials and Methods}

\subsection{Study sites}

I developed this study in three large remnants of dense Cerrado, which, as a habitat type, resembles the dry forests due to a low and almost continuous canopy, besides the deciduous pattern during the dry season (Ribeiro and Walter, 1998). The remnants were: Matão $20^{\circ} 25^{\prime} 16^{\prime \prime} \mathrm{S}$, 5151'32" O, 1200 ha in area, São Matheus $20^{\circ} 27^{\prime} 33^{\prime \prime} \mathrm{S}$, 51 38'36" O, 753 ha; Bom Jardim 20³0'40.8” S, 52³1'49”O, 667 ha, all of which are private reserves located in the Municipality of Três Lagoas, State of Mato Grosso do Sul, Brazil; 51 $48^{\circ} \mathrm{W}, 20^{\circ} 46^{\prime} \mathrm{S}$, elevation $340 \mathrm{~m}$. The clearing of Cerrado in this region has produced landscape that are mosaics of pastures with isolated trees, riparian forest remnants, palm (Mauritia L.f.) stands remnants, and Cerrado fragments. Cerrado remnants mentioned above were spaced by at least $23 \mathrm{~km}$. Some common trees present in the remnants are Qualea grandiflora Mart., $Q$. parviflora Mart., Copaifera langsdorfii Desf., Dipteryx alata Vog., Pterodon emarginatus Vogel, Annona crassiflora Mart., Anadenanthera falcata (Benth.) Speg. and Vatairea macrocarpa (Benth.) Ducke. The canopy in these remnants was 6-10 m tall, while emergent trees may reach $12-14 \mathrm{~m}$. From June to September, most tree species shed their leaves, contributing to a deciduous pattern. Annual rainfall is around $1400 \mathrm{~mm}$, most of which (70-80\%) occurs from October to March (wet season). During the wet season average temperature is $24{ }^{\circ} \mathrm{C}$, whereas, during the dry season (April to September) an average of $17^{\circ} \mathrm{C}$ is recorded. Frosts may occur in the coldest months.

\subsection{Study species}

Syagrus flexuosa (Mart.) Becc. is present in the Cerrado of São Paulo, Minas Gerais, Mato Grosso do Sul, Mato Grosso, Goiás, Tocantins, Maranhão, and Bahia states (Lorenzi et al., 2010). This palm reaches 1-5 m high, and the crown has 7-15 leaves 0.9-1.1 m long, in which leaflets (40-80 at each side) are regularly arranged in different planes (Lorenzi et al., 2010). It occurs both in preserved and disturbed Cerrado, as well as in anthropized areas as pastures. It produces one to four infructescences per stem, each with 1 to 60 ovoid fruits $(3.0-6.0 \mathrm{~cm}$ in length; 2.0 $3.0 \mathrm{~cm}$ in diameter) with a fleshy edible pulp, and a highlynutritious, coconut-like endosperm (Lorenzi et al., 2010). Syagrus flexuosa fruiting occurs all year round, and seeds are dispersed by mammals (Henderson, 2002). Mature individuals often produce fruits once a year (Henderson, 2002). At the study sites, mammals as Tapirus terrestris (Linnaeus, 1758), Dasyprocta sp. (Illiger, 1811), Thrichomys apereoides (Lund, 1839), and Clyomys sp. (Thomas, 1916), are putative S. flexuosa seed dispersers (Zona and Henderson, 1989; Marinho-Filho et al., 2002). Except for T. terrestris, and in addition to Cuniculus paca (Linnaeus, 1776), all other species also prey on S. flexuosa seeds.

\subsection{Sampling}

At the edge and in the interior (habitat types) of Cerrado remnants, I sampled seedling abundance (August 2018) according to the distance from adult palms. To do 
that, in each Cerrado remnant, I delimited one transect in the edge at $25 \mathrm{~m}$ from the Cerrado boundary and one transect in the interior at $600 \mathrm{~m}$ away from the edge. Initially, I searched for adult palm individuals, identified by the presence of infructescence or vestiges of previous fruiting events. Then, I randomly selected at each habitat type 10 adult individuals (height $\geq 3 \mathrm{~m}$ ) located in flat areas at least $40 \mathrm{~m}$ away from the nearest conspecific adult. For each adult individual, I counted seedlings along four $20-\mathrm{m}$ transects, which were randomly set starting from the base of the palm stem. To count seedlings, in each transect, five plots of $3 \mathrm{~m}^{2}$ (rectangle of $1 \mathrm{~m}$ [width] x $3 \mathrm{~m}$ [length]) were positioned at every $5 \mathrm{~m}$ from the adult palm (presumably parent; $0,5,10$, 15 , and $20 \mathrm{~m}$ ). Non-dispersed fruits may be found on the soil surface under palm crowns (commonly from 0.5 to $2-3 \mathrm{~m}$ radius from the base of the palm stem) after falling from the infructescence. Thus, seedlings found up to $3 \mathrm{~m}$ from a given focal adult palm (i.e., under the palm crown) were considered as originating from non-dispersed seeds. On the other hand, those located between $>3 \mathrm{~m}$ and $23 \mathrm{~m}$ away from palms were assumed as originating from dispersed seeds (Dracxler et al., 2011; Andreazzi et al., 2012). Seedlings had simple leaves and no stem, or had pinnate leaves and also no stem. In both cases, I counted, only seedlings smaller than $25 \mathrm{~cm}$ in height. I defined this ontogenetic criterion in order to evaluate early seedling establishment resulting from recent animal dispersal events, in face of the focus on the edge effect on seedling recruitment. Both in the edge and interior, seedlings were easily detected due to the scarce understory.

\subsection{Data analysis}

To compare the abundance of seedlings between the edge and interior of each remnant, I used a t-test in which I took as a replicate the number of seedlings sampled per parent palm; these data were log-transformed to achieve normality. To compare seedling distribution along distance classes from parent palms [edge versus interior], I used a Chi-square contingency analysis. In each edge or interior of every remnant, I took the accumulated number of seedlings sampled at each distance class to compare their distribution at edges with at interiors. In a contingency table, columns (distance class $[0,5,10,15$, and $20 \mathrm{~m}]$ ) represent the different states of one nominal variable, while rows (habitat type [edge or interior]) represent the states of another nominal variable. The cells include the counts of occurrences (accumulated number of seedlings) of that specific state (distance class, habitat type) of the two variables. The significance of association between the two variables (based on chi-squared) is then given, with $p$ values from the chi-squared distribution. The contingency table analysis then gives information on whether the two variables are associated.

\section{Results}

Along the Matão edge, seedlings around parent palms ranged from 2 to 29 (average \pm se: $8.2 \pm 2.5, \mathrm{~N}$ $=82$ seedlings), while in the interior ranged from 4 to $27(13.4 \pm 2.2, \mathrm{~N}=134)$. This difference was significant ( $t$-test, $t=2.18, P<0.050)$. In the São Matheus the number of seedlings was also higher in the interior (from 2 to 27; $9.6 \pm 2.4, \mathrm{~N}=96$, versus [at the edge] from 1 to $11 ; 4.7 \pm 1.1$, $\mathrm{N}=47, \mathrm{t}=2.02, \mathrm{P}<0.050$ ), as well as in the Bom Jardim remnant (interior: from 2 to $13 ; 8.4 \pm 1.2, \mathrm{~N}=84$, versus edge: from 1 to $11 ; 5.7 \pm 1.3, \mathrm{~N}=57, \mathrm{t}=2.05, \mathrm{P}<0.050$; Figure 1). Seedling distribution across distance classes differed between habitat types. For palms located at the edges, most seedlings were found under parent crowns (Matão: 69.5\%, São Matheus: 53.2\%, and Bom Jardim: $56.6 \%)$, while the contrary occurred in the interiors, where most seedlings were found away ( $>3 \mathrm{~m}$ ) from palm individuals (Matão: 30.6\%, São Matheus: 32.3\%, and Bom Jardim: 19.0\%; contingency, Matão: $\chi^{2}=40.27$, $\mathrm{P}<0.0002$, São Matheus: $\chi^{2}=10.48, \mathrm{P}<0.030$, and Bom Jardim: $\chi^{2}=21.68, \mathrm{P}<0.0003$; Figure 2 ).

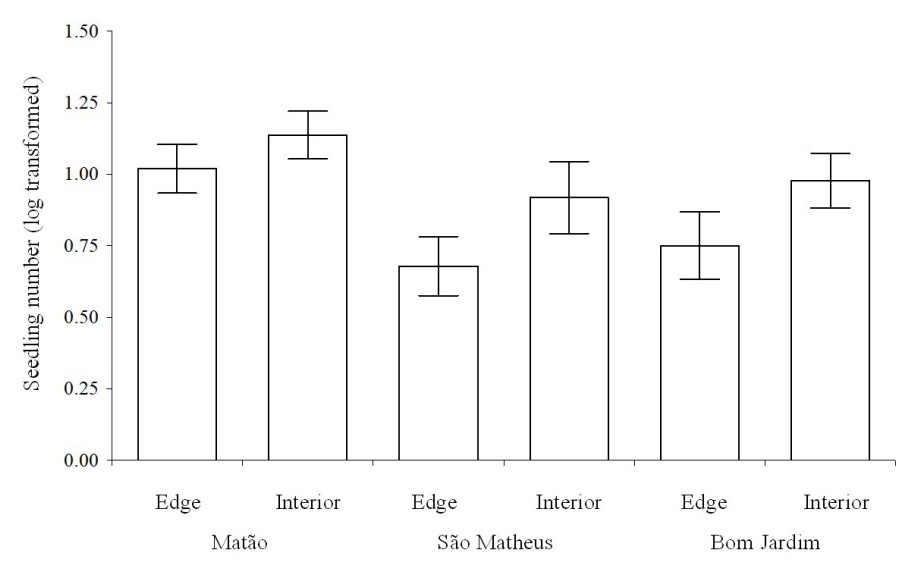

Figure 1. Number of Syagrus flexuosa seedlings (log transformed) found around parent palms at the edge and in the interior of Cerrado remnants (namely Matão, São Matheus, and Bom Jardim; Três Lagoas, MS, Brazil, August 2018). Bars show mean \pm standard errors. 

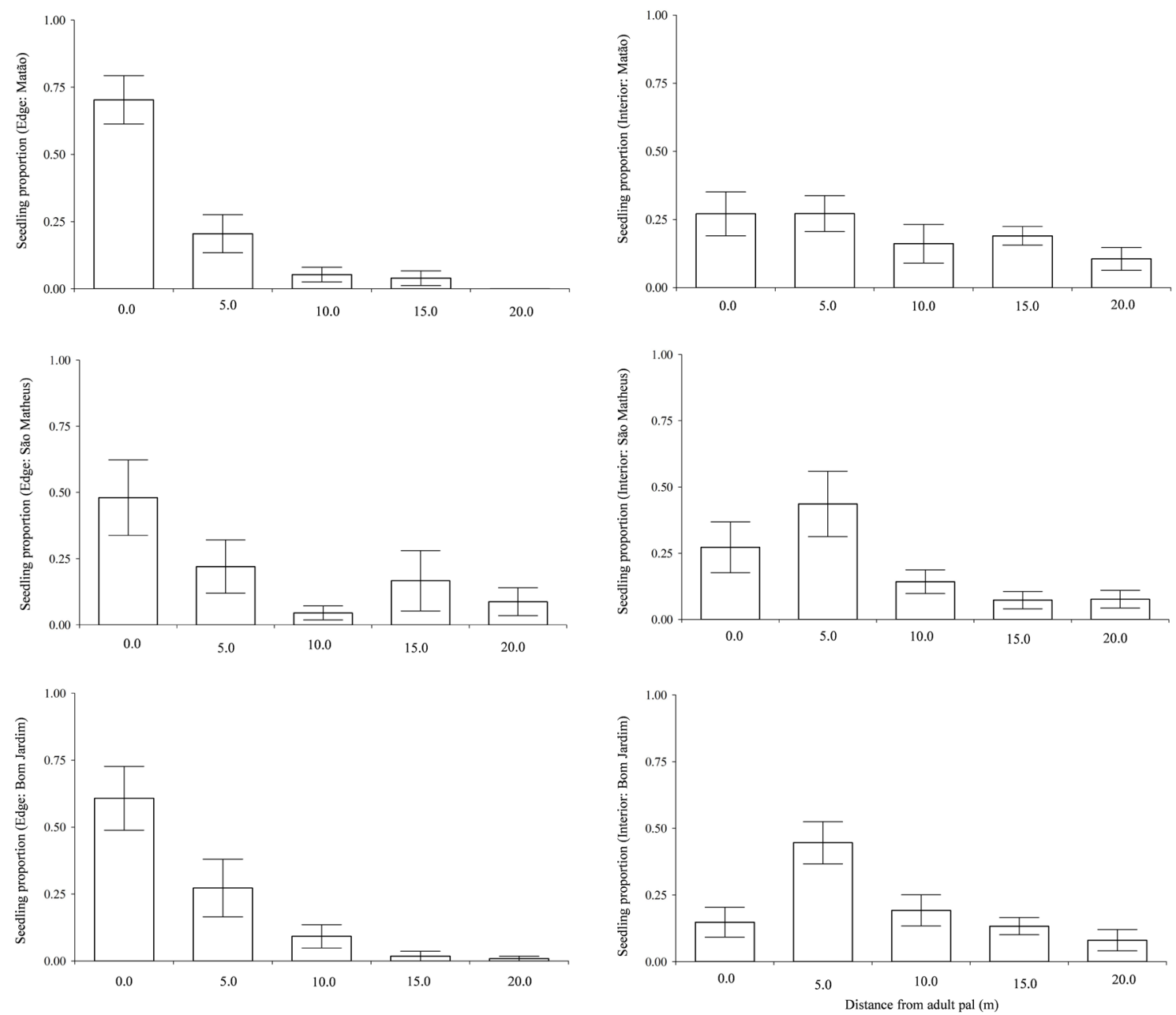

Figure 2. Proportions of Syagrus flexuosa seedlings found at different distance classes from parent palms at the edge and interior of Cerrado remnants (namely Matão, São Matheus, and Bom Jardim; Três Lagoas, MS, Brazil, August 2018). Bars show mean \pm standard errors.

\section{Discussion}

It is well known that seed dispersal can decrease the spatial seedling aggregation by spreading seeds over a larger area (Howe et al., 1985; Galetti et al., 2006; Dracxler and Forget, 2017). Moreover, studies have demonstrated that seed removal depends positively on disperser abundance (Alcántara et al., 1997). In the interior of Cerrado remnants, the higher number of seedlings found far from parent palms may reflect the persistence of the seed dispersal process (Howe et al., 1985; De la Peña-Domene et al., 2016). Scatter-hoarding rodents, for example, commonly move palm seeds of distances between 5-10 m from the seed source (Jansen et al., 2014; Dracxler and Kissling, 2021), which, in the interiors, is coherent to the observed distribution of seedlings around parent palms. On the other hand, the high seedling concentration under parent palms suggest that large-seeded dispersers interact less with S. flexuosa fruits present in the edges (Silva and Tabarelli, 2000; Ragusa-Netto, 2017). Presumably, once on the soil, most $S$. flexuosa fruits continued untouched, as documented in other anthropized areas (Wright and
Duber, 2001; Ragusa-Netto, 2017). Indeed, in sites where key seed dispersers were extirpated, large-seeded palm species suffer limitations on long-distance seed dispersal (Wright and Duber, 2001). In these conditions, important to consider the potential density-dependent seed mortality caused by natural enemies under parent palms (Janzen, 1971; Johnson et al., 1995; Terborgh, 2012; Ragusa-Netto, 2019). Syagrus flexuosa produce fruits asynchronously (Henderson, 2002), and, during the dry season curculionid larvae (Revena sp Casey, 1922) prey on average, only 9\% of their seeds (Ragusa-Netto, J, unpublished results). Then, the diaspores accumulated under palms during the diapause of bruchid beetles (dry season), might experience a less severe mortality rate (Wright, 1990). Starting the wet season, those intact seeds might germinate (Gandolfi et al., 2007). The reduced seed dispersal added to a decreased seed mortality during the dry season is coherent with seedling concentration under adult trees (Silva and Tabarelli, 2000). According to that, in sites where large-seed dispersers declined, an increase of seedling patches has been documented due to seed accumulation beneath parent palms (Wright and Duber, 2001). Even 
then, despite the initial development, it is important to consider that seedlings may become unable to growth close to parents, incurring in mortality process (Gandolfi et al., 2007). Many studies have shown that seedling mortality rates are higher near conspecific adults (Wright, 2002). In the studied edges, no late-stage seedling or sapling was present close to adult palms, suggesting a reduced recruitment process under adults $S$. flexuosa.

Herbivores as peccaries, tapirs, and ants often feed on palm seedlings (Silman et al., 2003; Wirth et al., 2008). All of them occurred in the studied fragments (RagusaNetto, J., pers. obs.), and it is unlikely that, only in the interior, those herbivores consumed seedlings close to adult palms. Actually, the edge vegetation often favors generalist herbivores, which may exert an important regulatory role on seedling abundance at these areas (Wirth et al., 2008). Syagrus flexuosa seedlings were less abundant at edges but common close to adult individuals, suggesting a decline of interactions with medium-large seed vectors (Wright and Duber, 2001; Muñoz et al., 2019). Although some palm species can exhibit increased abundance along forest edges (Souza and Martins, 2003; Pimentel and Tabarelli, 2004), I documented here that S. flexuosa individuals found at Cerrado fragment edges show patterns of seedling abundance and distribution unfavorable to an intense regeneration process (Benítez-Malvido et al., 2018). Then, because $S$. flexuosa is a widely distributed palm that serves as an important resource for several animals across Cerrado habitats (Lorenzi et al., 2010), changes in their regeneration process due to edge effects can further impact frugivore populations. In this respect, as the recruitment of large-seeded tree species arises as a priority to tropical vegetation conservation (Melo et al., 2007), S. flexuosa progressive rarity at fragments' edges implies substantial changes that may compromise the persistence of other species and ecological processes, as well (Peters et al., 2008; Arroyo-Rodríguez et al. 2007; Benítez-Malvido et al., 2018). Moreover, the differences between edges and interiors in the seedling recruitment process observed here may be widespread among other large-seeded tree species (Melo et al., 2007; RagusaNetto, 2017). Thus, Cerrado fragments might have similar problems of species impoverishment, as documented for tropical forests (Silva and Tabarelli, 2000; Melo et al., 2007; Tabarelli et al., 2008; Browne and Karubian, 2016). In this way, with only half of its original area left, the accelerated clearing of Cerrado needs urgent interruption (Carvalho et al., 2009; Beuchle et al., 2015). Conservation actions to re-establish $S$. flexuosa populations at edges may require the management of Cerrado remnants to imitate undisturbed sites, thereby preventing mortality of adult palms and promote the recruitment of juveniles.

\section{Acknowledgements}

Financial support was provided by Propp - UFMS. The comments of an anonymous reviewer improved the final version of this study. I am indebted to Caroline M. Dracxler for the thoughtful review and constructive comments on a draft of this study.

\section{References}

ALCÁNTARA, J.M., REY, P.J., VALERA, F., SÁNCHEZ-LAFUENTE, A.M., GUTIÉRREZ, J.E., ALCANTARA, J.M., SANCHEZ-LAFUENTE, A.M. and GUTIERREZ, J.E., 1997. Habitat alteration and plant intraspecific competition for seed dispersers: an example with Olea europaea var. sylvestris. Oikos, vol. 79, no. 2, pp. 291-300. http://dx.doi.org/10.2307/3546013.

ANDREAZZI, C.S., PIMENTA, C.S., PIRES, A.S., FERNANDEZ, F.A.S., OLIVEIRA-SANTOS, L.G. and MENEZES, J.F.S., 2012. Increased productivity and reduced seed predation favor a large-seeded palm in small Atlantic Forest fragments. Biotropica, vol. 44, no. 2, pp. 237-245. http://dx.doi.org/10.1111/j.1744-7429.2011.00782.x.

ARROYO-RODRÍGUEZ, V., AGUIRRE, A., BENÍTEZ-MALVIDO, J. and MANDUJANO, S., 2007. Impact of rain forest fragmentation on the population size of a structurally important palm species: Astrocaryum mexicanum at Los Tuxtlas, Mexico. Biological Conservation, vol. 138, no.1-2, pp. 198-206. http://dx.doi.org/10.1016/j.biocon.2007.04.016.

ASQUITH, N.M. and MEJÍA-CHANG, M., 2005. Mammals, edge effects, and the loss of tropical forest diversity. Ecology, vol. 86, no. 2, pp. 379-390. http://dx.doi.org/10.1890/03-0575.

BAEZ, S. and BALSLEV, H., 2007. Edge effects on palm diversity in rain forest fragments in western Ecuador. Biodiversity and Conservation, vol. 16, no. 7, pp. 2201-2211. http://dx.doi. org/10.1007/s10531-007-9159-5.

BENÍTEZ-MALVIDO,J., 1998. Impact of forest fragmentation on seedling abundance in a tropical rain forest. Conservation Biology, vol. 12, no. 2, pp. 380-389. http://dx.doi.org/10.1046/j.1523-1739.1998.96295.x.

BENÍTEZ-MALVIDO, J., LÁZARO, A. and FERRAZ, I.D., 2018. Effect of distance to edge and edge interaction on seedling regeneration and biotic damage in tropical rainforest fragments: A long-term experiment. Journal of Ecology, vol. 106, no. 6, pp. 2204-2217. http://dx.doi.org/10.1111/1365-2745.13003.

BEUCHLE, R., GRECCHI, R.C., SHIMABUKURO, Y.E., SELIGER, R., EVA, H.D., SANO, E. and ACHARD, F., 2015. Land cover changes in the Brazilian Cerrado and Caatinga biomes from 1990 to 2010 based on a systematic remote sensing sampling approach. Applied Geography (Sevenoaks, England), vol. 58, no. 2, pp. 116-127. http://dx.doi.org/10.1016/j.apgeog.2015.01.017.

BROWNE, L. and KARUBIAN, J., 2016. Diversity of palm communities at different spatial scales in a recently fragmented tropical landscape. Botanical Journal of the Linnean Society, vol. 182, no. 2, pp. 451-464. http://dx.doi.org/10.1111/boj.12384.

CARVALHO, F.M.V., DEMARCO, P.J. and FERREIRA, L.G., 2009. The Cerrado into-pieces: habitat fragmentation as a function of landscape use in the savannas of Central Brazil. Biological Conservation, vol. 142, no. 7, pp. 1392-1403. http://dx.doi.org/10.1016/j.biocon.2009.01.031.

CORDEIRO, N.J. and HOWE, H.F., 2003. Forest fragmentation severs mutualism between seed dispersers and an endemic African tree. Proceedings of the National Academy of Sciences of the United States of America, vol. 100, no. 24, pp. 14052-14056. http://dx.doi.org/10.1073/pnas.2331023100. PMid:14614145.

DE LA PEÑA-DOMENE, M., MINOR, E.S. and HOWE, H.F., 2016. Restored connectivity facilitates recruitment by an endemic large-seeded tree in a fragmented tropical landscape. Ecology, vol. 97, no. 9, pp. 2511-2517. http://dx.doi.org/10.1002/ecy.1459. PMid:27859068.

DRACXLER, C., PIRES, A.S. and FERNANDEZ, F.A.S., 2011. Invertebrate seed predators are not all the same: seed predation by bruchine and scolytine beetles affects palm recruitment in different ways. Biotropica, vol. 43, no. 1, pp. 8-11. http://dx.doi. org/10.1111/j.1744-7429.2010.00723.x.

DRACXLER, C.M. and FORGET, P.M., 2017. Seed caching by rodents favors seedling establishment of two palm species in a lowland Atlantic forest remnant. Journal of Tropical Ecology, vol. 33, no. 3, pp. 228-231. http://dx.doi.org/10.1017/S0266467417000128.

DRACXLER, C.M. and KISSLING, W.D., 2021. The mutualismantagonism continuum in Neotropical palm-frugivore 
interactions: from interaction outcomes to ecosystem dynamics. Biological Reviews of the Cambridge Philosophical Society, pp. brv.12809. http://dx.doi.org/10.1111/brv.12809. PMid:34725900.

GALETTI, M., DONATTI, C.I., PIRES, A.S., GUIMARÃES JÚNIOR, P.R. and JORDANO, P., 2006. Seed survival and dispersal of an endemic Atlantic forest palm: the combined effects of defaunation and forest fragmentation. Botanical Journal of the Linnean Society, vol. 151, no. 1, pp. 141-149. http://dx.doi.org/10.1111/j.1095-8339.2006.00529.x.

GANDOLFI, S., JOLY, C.A. and RODRIGUES, R.R., 2007. Permeabilityimpermeability: canopy trees as biodiversity filters. Scientia Agrícola, vol. 64, no. 4, pp. 433-438. http://dx.doi.org/10.1590/ S0103-90162007000400015.

HENDERSON, A., 2002. Evolution and ecology of palms. New York: The New York Botanical Garden Press, 198 p.

HOWE, H.F., SCHUPP, E.W. and WESTLEY, L.C., 1985. Early consequences of seed dispersal for a neotropical tree (Virola surinamensis). Ecology, vol. 66, no. 3, pp. 781-791. http://dx.doi. org/10.2307/1940539.

JANSEN, P.A., VISSER, M.D., JOSEPH WRIGHT, S., RUTTEN, G. and MULLER-LANDAU, H.C., 2014. Negative density dependence of seed dispersal and seedling recruitment in a Neotropical palm. Ecology Letters, vol. 17, no. 9, pp. 1111-1120. http://dx.doi. org/10.1111/ele.12317. PMid:25039608.

JANZEN, D.H., 1971. The fate of Scheellea rostrata fruits beneath the parent tree: predispersal attack by bruchids. Principes, vol. 15 , no. 1 , pp. $89-101$.

JOHNSON, C.D., ZONA, S. and NILSSON, J.A., 1995. Bruchid beetles and palm seeds: recorded relationships. Principes, vol. 39, no. 1, pp. 25-35.

LAURANCE, W.F., NASCIMENTO, H.E., LAURANCE, S.G., ANDRADE, A.C., FEARNSIDE, P.M., RIBEIRO, J.E. and CAPRETZ, R.L., 2006. Rain forest fragmentation and the proliferation of successional trees. Ecology, vol. 87, no. 2, pp. 469-482. http://dx.doi. org/10.1890/05-0064. PMid:16637371.

LORENZI, H., NOBLICK, L., KAHA, F. and FERREIRA, E., 2010. Flora Brasileira: Arecaceae (Palms). Nova Odessa: Instituto Plantarium. 384 p.

MARIANO, V. and CHRISTIANINI, A.V., 2016. Reproductive phenology, seed removal and early regeneration in relation to distance from parental plants of a native palm in small Atlantic forest fragments. Acta Botanica Brasílica, vol. 30, no. 2, pp. 176-182. http://dx.doi.org/10.1590/0102-33062015abb0302.

MARINHO-FILHO, J., RODRIGUEZ, F.H.G. and JUAREZ, K.M., 2002. The Cerrado mammals: diversity, ecology and natural history. In: P.S. Oliveria, \& R.J. Marquis (Eds.). The cerrados of Brazil: ecology and natural history of a neotropical savanna. New York: Columbia University Press, pp. 266-286.

MELO, F.P.L., LEMIRE, D. and TABARELLI, M., 2007. Extirpation of large-seeded seedlings from the edge of a large Brazilian Atlantic forest fragment. Ecoscience, vol. 14, no. 1, pp. 124-129. http:// dx.doi.org/10.2980/1195-6860(2007)14[124:EOLSFT]2.0.CO;2.

MUÑOZ, G., TRØJELSGAARD, K. and KISSLING, W.D., 2019. A synthesis of animal-mediated seed dispersal of palms reveals distinct biogeographical differences in species interactions. Journal of Biogeography, vol. 46, no. 2, pp. 466-484. http:// dx.doi.org/10.1111/jbi.13493.

PETERS, M.K., LIKARE, S. and KRAEMER, M., 2008. Effects of habitat fragmentation and degradation on flocks of African ant-following birds. Ecological Applications, vol. 18, no. 4, pp. 847-858. http:// dx.doi.org/10.1890/07-1295.1. PMid:18536247.

PIMENTEL, D.S. and TABARELLI, M., 2004. Seed dispersal of the palm Attalea oleifera in a remnant of the Brazilian Atlantic Forest. Biotropica, vol. 36, no. 1, pp. 74-84. http://dx.doi. org/10.1111/j.1744-7429.2004.tb00298.x.
RAGUSA-NETTO, J., 2017. Seed removal of Dipteryx alata Vog. (Leguminosae: Faboidae) in the edge and interior of Cerrado. Brazilian Journal of Biology = Revista Brasileira de Biologia, vol. 77, no. 4, pp. 752-761. http://dx.doi.org/10.1590/1519-6984.20715. PMid:28355393.

RAGUSA-NETTO, J., 2019. Density-dependent seed predation in Attalea geraensis Barb. Rodr. (Arecaceae) caused by bruchid beetles in the Brazilian Cerrado. Brazilian Journal of Biology = Revista Brasileira de Biologia, vol. 79, no. 4, pp. 577-583. http:// dx.doi.org/10.1590/1519-6984.183318. PMid:30365636.

RIBEIRO, J.F. and WALTER, B.M.T., 1998. Fitofisionomias do cerrado. In: S.M. SANO and S.P. ALMEIDA, eds. Cerrado: ambiente e flora. Planaltina: Embrapa, pp. 89-166.

SCARIOT, A., 1999. Forest fragmentation effects on palm diversity in central Amazonia. Journal of Ecology, vol. 87, no. 1, pp. 66-76. http://dx.doi.org/10.1046/j.1365-2745.1999.00332.x.

SILMAN, M.R., TERBORGH, J.W. and KILTIE, R.A., 2003. Population regulation of a dominant rain forest tree by a major seed predator. Ecology, vol. 84, no. 2, pp. 431-438. http://dx.doi. org/10.1890/0012-9658(2003)084[0431:PROADR]2.0.CO;2.

SILVA, J.M.C. and TABARELLI, M., 2000. Tree species impoverishment and the future flora of the Atlantic forest of northeast Brazil. Nature, vol. 404, no. 6773, pp. 72-74. http://dx.doi. org/10.1038/35003563. PMid:10716443

SOUZA, A.F. and MARTINS, F.R., 2003. Spatial distribution of an undergrowth palm in fragments of the Brazilian Atlantic Forest. Plant Ecology, vol. 164, no. 2, pp. 141-155. http://dx.doi. org/10.1023/A:1021229832634.

TABARELLI, M., LOPES, A.V. and PERES, C.A., 2008. Edge-effects drive tropical forest fragments towards an early-successional system. Biotropica, vol. 40, no. 6, pp. 657-661. http://dx.doi. org/10.1111/j.1744-7429.2008.00454.x.

TERBORGH, J., 2012. Enemies maintain hyperdiverse tropical forests. American Naturalist, vol. 179, no. 3, pp.303-314. http://dx.doi. org/10.1086/664183. PMid:22322219.

WIRTH, R., MEYER, S.T., LEAL, I.R. and TABARELLI, M., 2008. Plant herbivore interactions at the forest edge. Progress in Botany, vol. 68, no. 1, pp. 423-448. http://dx.doi.org/10.1007/978-3540-72954-9_17.

WRIGHT, J.S., 2002. Plant diversity in tropical forests: a review of mechanisms of species coexistence. Oecologia, vol. 130, no. 1, pp. 1-14. http://dx.doi.org/10.1007/s004420100809. PMid:28547014.

WRIGHT, S.J. and DUBER, H.C., 2001. Poachers and forest fragmentation alter seed dispersal, seed survival, and seedling recruitment in the Palm Attalea butyraceae, with implications for tropical tree diversity. Biotropica, vol. 33, no. 4, pp. 583-595. http://dx.doi.org/10.1111/j.1744-7429.2001.tb00217.x.

WRIGHT, S.J., 1990. Cumulative satiation of a seed predator over the fruiting season of its host. Oikos, vol. 58, no. 3, pp. 272-276. http://dx.doi.org/10.2307/3545217.

WRIGHT, S.J., STONER, K.E., BECKMAN, N., CORLETT, R.T., DIRZO, R., MULLER-LANDAU, H.C., NUÑEZ-ITURRI, G., PERES, C.A. and WANG, B.C., 2007. The plight of large animals in tropical forests and the consequences for plant regeneration. Biotropica, vol. 39, no. 3, pp. 289-291. http://dx.doi.org/10.1111/j.1744-7429.2007.00293.x.

WRIGHT, S.J., ZEBALLOS, H., DOMÍNGUEZ, I., GALLARDO, M.M., MORENO, M.C. and IBÁÑEZ, R., 2000. Poachers alter mammal abundance, seed dispersal, and seed predation in a Neotropical forest. Conservation Biology, vol. 14, no. 1, pp. 227-239. http:// dx.doi.org/10.1046/j.1523-1739.2000.98333.x.

ZONA, S. and HENDERSON, A., 1989. A review of animal-mediated seed dispersal of palms. Selbyana, vol. 11, no. 1, pp. 6-21. 